\title{
Emergent Sign-Action
}

Classical Ballet As A Self-Organized And Temporally Distributed Semiotic Process

Pedro Atã and João Queiroz

\section{(2) OpenEdition}

1 Journals

\section{Electronic version}

URL: http://journals.openedition.org/ejpap/1652

DOI: $10.4000 /$ ejpap. 1652

ISSN: 2036-4091

\section{Publisher}

Associazione Pragma

\section{Electronic reference}

Pedro Atã and João Queiroz, "Emergent Sign-Action », European Journal of Pragmatism and American Philosophy [Online], XI-2 | 2019, Online since 24 December 2019, connection on 16 June 2020. URL : http://journals.openedition.org/ejpap/1652 ; DOI : https://doi.org/10.4000/ejpap.1652

This text was automatically generated on 16 June 2020 .

\section{(c) (i) (9)}

Author retains copyright and grants the European Journal of Pragmatism and American Philosophy right of first publication with the work simultaneously licensed under a Creative Commons AttributionNonCommercial-NoDerivatives 4.0 International License. 


\title{
Emergent Sign-Action
}

Classical Ballet As A Self-Organized And Temporally Distributed Semiotic Process

\author{
Pedro Atã and João Queiroz
}

\section{AUTHOR'S NOTE}

The authors thank the anonymous reviewers for valuable comments.

\section{Introduction: Overall Argument}

In this paper, we explore C.S. Peirce's pragmatic conception of sign action as a temporally distributed and emergent process. ${ }^{1}$ We illustrate our argument through the emergence of classical ballet as a semiotic process. Pragmatism was originally formulated by Peirce as a theory of meaning, a methodological principle or rule to clarify ideas, concepts and propositions (Hookway 2002; Legg \& Hookway 2019). This principle states that the meaning of a sign implies likely events to occur in a course of experience, according to a set of antecedent conditions (CP 5.468). In this formulation, meaning is an open ended process, constrained by likelihoods, but open to novelty. The meaning of a sign is not a given content nor an essential form, but emerges as a habit of sign action.

Semiosis emerges (see Queiroz \& El-Hani 2006a,b). The emergence of a sign in action is the emergence of an autonomous, or self-organized, habit. Self-organization is a process that leads a complex system towards dynamically stable states of increased redundancy and reduced variability. In our description, stability is not absence of change (stasis), but regularity through change (Kelso 1995). Peirce's theory is compatible with the notion of self-organization, especially when we consider how semiotic habits stabilize communication within a system (a community) of utterers and interpreters, through self-correcting dynamics and circular relations within that community (Loula \& Queiroz 2011). New habits of sign action emerge from previously 
existing sign action in a cultural evolutionary process. Out of semiosis that follows some stability and tendency of development, new habits become stabilized and begin to develop autonomously. In our description, this corresponds to the emergence of a distributed cognitive system of agents and artifacts which both enacts this habit and is regulated by it (Atã \& Queiroz, in press). An example is the historical emergence of classical ballet. Classical ballet is a habit of sign action: a codification of dance steps that disciplines bodies and stabilizes their communicative behavior within a community of utterers and interpreters. The historical emergence of classical ballet is a self-regulatory process, in which a system of different kinds of cognitive artifacts (musical, bodily/motor, visual, spatial/architectonic) and agents obtained a stable semiotic relation throughout many phases of development between the 16th and 19th Century. This is not only emergence of actual meaning, but also, emergence of an open-ended niche of potential and general meaning processes, an autonomous tendency of development or a pragmatic likelihood of occurrences.

\section{Meaning and Habit}

Peirce is the founder of modern semiotics, the doctrine of the essential and fundamental nature of all varieties of possible meaning processes [i.e., semiosis, or sign action] (CP 5.484). Semiotics describes and analyzes the structure of sign action independently of their material bases, or of the conditions under which they can be observed: inside cells (cytosemiosis), among tissues and cell populations, in animal communication (zoosemiosis), or in typically human activities (production of notations, metarepresentations, etc.). In other words, Peirce's concept of semiotics concerns a theory of signs in its most general sense (Fisch 1986: 321). Peirce conceived general semiotics much like a formal science as mathematics is (CP 2.227). However, semiotics finds the objects of its investigation in the sign's concrete, natural environment and in "normal human experience" (CP 1.241). In our example, the object of investigation is the emergence of classical ballet.

An approach to meaning that focuses on the action of signs can be contrasted to approaches that focus either primarily on the sign itself (formalist and structuralist approaches) or on the sign-user (psychological, neurocognitive, anthropological and sociological approaches). Semiosis is a concept that describes the most fundamental relations involved in processes of meaning and cognition, as opposed to reactive, bruteforce processes (EP 2:646). The difference between semiotic and non-semiotic processes is that non-semiotic processes can be decomposed into dyadic or reactive processes, while semiotic processes are irreducibly triadic (Houser 1997: 16; Burch 1997; Brunning 1997). Any description of semiosis should necessarily treat it as a relation constituted by three irreducibly connected terms - sign, object, interpretant (S-O-I, in short), which are its minimal constitutive elements (CP 5.484, EP 2:171).

[...] by "semiosis" I mean [...] an action, or influence, which is, or involves, a cooperation of three subjects, such as a sign, its object, and its interpretant, this trirelative influence not being in any way resolvable into actions between pairs. (CP 5.484)

Triadic irreducibility is a requirement of any process that we might regard as "cognitive," "representational," or related to "meaning" - "A sign, or representamen, is something which stands to somebody for something in some respect or capacity" (CP 2.228). The expression stand for is metaphorical. This "standing for" relation involves a 
constraining or regulation of $\mathrm{S}$ (sign) by $\mathrm{O}$ (object) ( $\mathrm{S}$ is understood in relation to $\mathrm{O}$ ) (Atkin 2016). I (interpretant) in S-O-I is an effect produced in a cognitive system by the use of $\mathrm{S}$ as constrained by $\mathrm{O}$. Semiosis is an irreducible process through which a constraining factor (O) acts on interpretative behavior (I) because of the mediation of a certain entity (or group of entities) or process (S).

It is important to stress that there are no intrinsic attributes defining the ontology or the spatiotemporal existence of S, O, or I. They are not necessarily phenomenal contents, intentional contents, mental representations, concepts, thoughts, etc. The role of $\mathrm{S}$ can be identified only in the mediative relation that it establishes between $\mathrm{O}$ and I. Similarly, the role of $O$ is identified in the relation by which it determines I through the mediation of S. And, finally, the role of I is identified by the fact that it is determined by $\mathrm{O}$ through $\mathrm{S}$. Therefore, if we consider only dyadic relations, S-I, S-O, or $\mathrm{I}-\mathrm{O}$, or the elements in isolation, we cannot deduce how they would behave in a triadic relation, S-O-I (EP 2:391). Irreducibility of semiosis should be understood in terms of the non-deducibility of the behavior of the logical-functional elements of a triad on the grounds of their behavior in simpler relations.

Peirce also defined a sign as a medium for the communication to the interpretant of a "form" embodied in the object, so as to constrain or regulate, in general, the interpreter's behavior (MS 793:1-3, EP 2.544, n.22). Form is defined as having the "being of predicate" (EP 2.544) and it is also pragmatically formulated as a "conditional proposition" stating that certain things would happen under specific circumstances (EP 2.388). For Peirce, form is nothing like a "thing" (De Tienne, 2003), but something that is embodied in the object (EP 2.544, n. 22) as a habit, a "rule of action" (CP 5.397, CP 2.643), a "disposition" (CP 5.495, CP 2.170), a "real potential" (EP 2.388) or, simply, a "permanence of some relation" (CP 1.415). Form can also be defined as potentiality ("real potential," EP 2.388). According to Flower and Murphey, there is a transition in Peirce's semiotics from the notion of meaning as a qualitative conception carried by a sign to a relational notion according to which the meaning of a concept consists in a "law relating operations performed upon the object or conditions of perceptions to perceived effects" (Flower \& Murphey 1977: 589). The qualitative conception involves reference to the sign's ground, while the "law" or necessary conditions of perception are relational rather than qualitative - "If the meaning of a concept of an object is to consist in the conditionals relating operations on the object to perceived effects, these conditionals will in fact be habits" (Flower \& Murphey 1977: 590).

The notion of habit occupies a central position in Peirce's pragmatism (Hookway 1985; West \& Anderson 2016; Atã \& Queiroz 2016). Habit entails a disposition to act in certain ways under certain circumstances, especially when the carrier of the habit is stimulated, animated, or guided by certain motives (CP 5.480). The meaning of a Peircean sign is most adequately understood through the habits of action they provoke, sustain, and modify. When somebody says a diamond is "hard," that person means that a diamond's nature includes the ability to cut glass and other substances. That person's disposition to conceive of a diamond in this way - rather than conceiving it for ornamental purposes - constitutes, pragmatically, what "hardness" means, and "diamond" means in terms of its characteristics and its nature. If that person had once considered diamonds strictly in terms of rare gems and ornamentation, then the characteristics and nature of diamonds were previously something other than they now are. Consequently, the meaning of "diamond" changed when a diamond became a 
means for qualifying "hardness." This is to say that the notion of semiosis as form communicated from $\mathrm{O}$ to I through mediation of $\mathrm{S}$ allows us to conceive of semiosis, and meaning and meaning change, in a non-substantive, processual way, as a constraining factor of possible patterns of interpretive behavior through habit and change of habit (Queiroz \& El-Hani 2006a).

Let's consider our main example. Classical ballet is a semiotic process endowed with meaning. Any ballet performance is an instantiated sign, composed of several signs, and which determines interpretive effects according to some regularity. In any ballet performance, a sign acts according to a regular habit that connects sign (performance), object (in a most general description, the "form" of ballet itself that regulates how signs behave), and interpretants (interpretive effects, for example on the audience). From the 16th to the 19th century, the ballet sign has taken several habits that regulate sign action, such as the codification of a vocabulary of dance steps with a specific nomenclature and notation, the establishment of the proscenium arch stage as the preferred technology regulating performance space, the standardization of training techniques and consequent relative regularization of the skills, bodies, and abilities of professional dancers, etc. All of these are cases in which variability has been decreased and redundancy increased, so that sign action becomes more regular. They all are part of what makes classical ballet a sign in action, endowed with a potential to further produce interpretants.

\section{Semiosis is Temporally Distributed}

Semiosis is part of an always ongoing process of communication, a "chain of triads" (see figure 1). S-O-I is the focal-factor of a dynamical process (Hausman 1993: 72). A sign in a given S-O-I triad will lead to the production of an interpretant, which, in turn, is a new sign in relation to the object of S. That is, an interpretant is both the third term of a previous triad and the first term (sign) of a subsequent triad (Savan 1988) (figure 1).

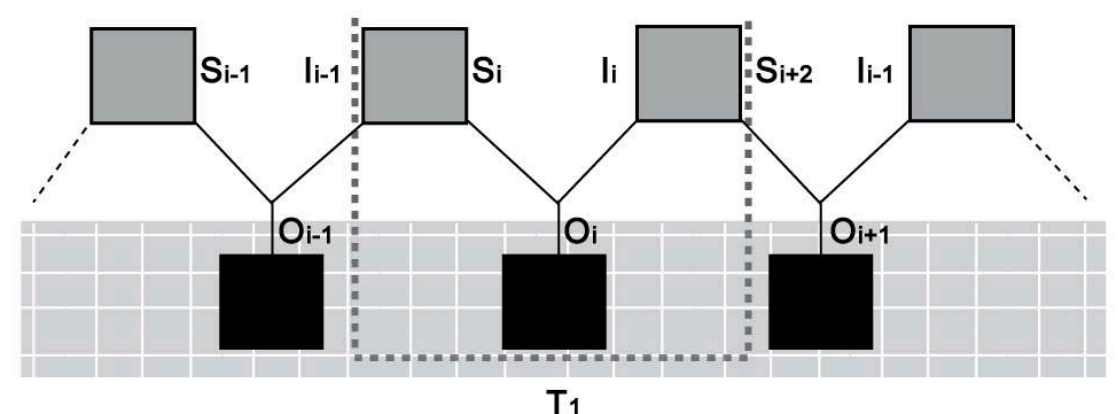

Figure 1: The triadic relation S-0-I forming a chain of triads.

Semiosis is a dynamic process, with signs continuously translating into other signs, in time. The mode of existence of a sign is to produce interpretative effects which are new 
signs. A single person thinking to herself already embodies a dynamic process of semiosis. This temporal distribution of semiosis is a central aspect of Peirce's semiotics:

To say, therefore, that thought cannot happen in an instant, but requires a time, is but another way of saying that every thought must be interpreted in another, or that all thought is in signs. (CP 5.253)

Semiosis is temporally distributed, a time-dependent action of signs which develops in several historical and evolutionary scales. To describe a habit of sign action is to describe a dynamic process involving past and future: a relation, developing in time, between a cumulative generalization of a past history of sign actions and a likelihood that this history will somehow regulate future sign actions. In this framework, stability of semiosis in time is not understood as an instantiation of representational states in a system but as regularity of sign action throughout communication. A habit doesn't entail stasis, but regularity throughout change.

Classical ballet entails semiotic chains in several different time scales. An instantiated sign of ballet, such as a ballet performance, has the power of generating new signs: a ballet performance generates interpretative effects in an audience, which develop into a critic literature about that performance, which in turn generates more interpretive effects, and so forth, constituting traditions of critique and discourse as sequences of reinterpretations and retranslations of ballet signs. Ballet performances also generate all sorts of artworks in different media (including other ballet performances) that dialogue with it by making reference, reinterpreting themes, taking inspiration, reacting aesthetically, and so on. But we don't need to consider only instantiated ballet performances as examples of how ballet entails semiotic chains. The body of the ballet dancer is a sign, being reinterpreted and translated throughout the history of ballet. The baroque courtier dancer of the 17th century is a sign endowed with a potential to generate interpretants. It gets translated into the professional academic dancers, the dancers of different ballet schools, all the way to modern and contemporary dancers. What connects all of these dancing bodies is a temporally distributed semiotic process, a semiotic chain that communicates some balletic forms so as to generate new ballet signs.

This process also entails an interplay between redundancy and novelty, a negotiation of the stability of semiotic habits. One of the most stable habits of classical ballet is the codification of the so-called five basic positions of the body (or, more precisely, the feet). The first position is a "gathering point" or resting position for the dancer (heels meeting at a central point and toes pointing outward), while the other four positions prepare the dancer to move (Homans 2010: 23) (see figure 2). Codified in the late 17th century by Pierre Beauchamp, the dancing master of Louis XIV, the five positions are the foundations of classical ballet:

The importance of these positions cannot be overstated: they are the major scale, the primary colors from which all other constructions in ballet arise. Without them, la belle danse was a social dance; with them, the crucial leap from etiquette to art was made. (Ibid.: 23) 

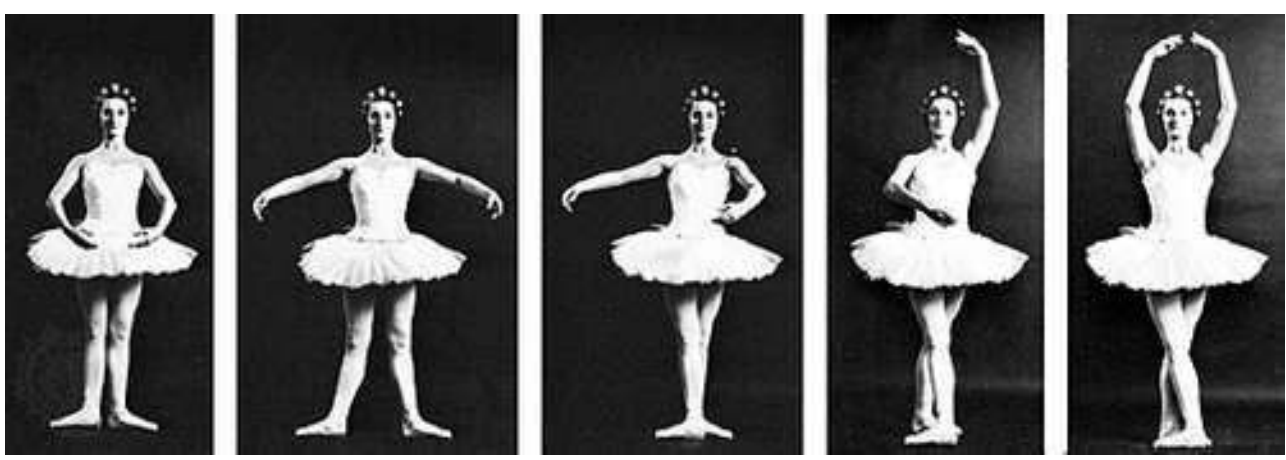

Figure 2: Five basic positions of the body

Between 16th and 19th century, dance changed radically: baroque dance became classical ballet, the nobles and courtiers were replaced by professional dancers, the palace halls and gardens were replaced by theaters with proscenium arch stages, the male predominance on stage was overcome by the central figure of the ballerina, and yet the five positions changed very little in comparison. To this day, they remain structurally the same, with the main transformation being a widening of the angle at which the feet point outward from the body (originally, the feet were never supposed to point outwards at an angle wider than 45 degrees).

However, this semiotic stability is not the same as propagation of a representational state or of informational content. The five positions of the feet discipline the dancer's movement so as to constrain the interpretative effects that the dance performance entails. Originally, this codification was carried out with the objective of making the dancer appear noble, as opposed to lesser social characters that were depicted as having the feet pointing inwards (ibid.: 23). But as ballet became more detached from etiquette, this distinction between the noble body and the body of the lower social classes became less pragmatically relevant for the action of the sign. In our description, the five positions of the body cannot be said to be a representational state or to convey an informational content. Its stability has the form of a habit of action, with openended results, across very distinct contexts and communicative situations. The semiotic character of the five positions of the feet is historical, temporally distributed: it is not synchronically located, and its object is a mere form that requires time and context to be expressed as a regularity.

This dynamic semiotic frame needs to be understood together with Peirce's pragmatism. The mode of being of signs is to act - determine effects - in the world. Semiosis is a process in which action and communication are co-dependent. This entails a semiotic kind of cognitive externalism: just as for Peirce it is impossible to think without signs, so also cognition itself is impossible without external, materiallyincorporated action and its consequences. Minds are not severed from the external world, but are continuous to it. ${ }^{2}$ To think with signs is to think with external artifacts and within a community.

This view of the temporal distribution of meaning has consequences for the notion of distributed cognitive systems (Zhang \& Patel 2006; Hutchins 2014; Davies \& Michaelian 2016), as it entails a "semiotization" of the discussion about distribution of cognition (see Atã and Queiroz, in press). Hutchins (2014) has characterized distributed cognition as an emergentist approach to cognition. In our approach, semiosis is a temporally 
distributed process in which a regular tendency towards certain future outcomes emerges out of a history of sign actions (a semiotic chain). Our approach here is pragmatic and action-oriented (cf. Engel, Friston \& Kragic 2016; Madzia \& Jung 2016), and focuses on sign action, as conceived by Peirce's pragmatism. According to the kind of cognitive externalism afforded by a Peircean perspective, whenever we consider distributed cognitive systems (DCS), we have to consider that the agents and artifacts in question embody irreducible semiotic processes. What makes some entity a part of a DCS is that, in the context of that system, the entity acts as a first term that triadically stands for a second term in order to determine a third term, which is a regular effect. In other words, what makes an entity a part of a DCS is that it acts as a sign so as to generate other signs. Why is it crucial to consider semiosis when describing DCSs? We cannot explain (it is not sufficient) the meaningful behavior of DCSs as the effects of explanatory units such as persons, groups of persons, or artifacts. The phenomenon to be described and explained when examining a DCS is the action of signs. Agents and artefacts in a DCS are observed as processes of irreducible triadic relations. DCSs and their meaningful behavior are outcomes of the action of signs. The fundamental unit of explanation for the behavior of persons and artefacts in a DCS are the signs that regulate them. The concept of semiosis is not a re-description of individual actions of agents and artifacts. In fact, the object of description here is not agents, artifacts, and their doings, but some real general process that supervenes on them but is not reducible to their particular properties. In this view, whenever one refers to an agent or a cognitive artifact in a DCS, he/she is referring to signs, and describing semiosis. In this active semiotic externalism, cognition is the development of available cognitive artifacts in which it is embodied as a power to produce interpretants (interpretative/ communicative effects).

Consider ballet: It is a habit of sign action, a codification of dance steps that disciplines bodies and stabilize their communicative behavior within a community of utterers and interpreters. This habit is temporally distributed. In the case of ballet, the agents of the DCS are dancers, audiences, choreographers, producers, theorists, critics, etc., that integrate a community within which "ballet" is a sign endowed with meaning. The artifacts of the DCS integrate an extensive list of items with which this large community enact the sign "ballet" as a process of meaning: dance notation systems, markings, musical notations and instruments, stage architecture and stage technologies, illumination devices, wearables, props and prostheses, literary artifacts such as narrative structures and character archetypes, print media such newspapers, magazines, books, etc. This extensive distributed cognitive system develops in time, from 16th century court dance to 20th century classical ballet. Throughout this time, agents and artifacts come and go, but the distributed system continues as a dynamical regularity throughout radically different circumstances and situations. This dynamical regularity evolves, changing its conditions of stability in several critical moments. This evolution takes the form of development of cognitive artifacts.

\section{Emergence of Semiosis}

Emergentism is a naturalistic and physicalistic (physical monist) position, according to which the evolution of physically constituted systems show critical turning points in which new organizational patterns arise, and, thus, new classes of systems exhibiting novel properties and processes. Emergentism assumes a hierarchy of levels of existence, 
and the distinction between non-systemic and systemic properties (i.e., properties observed at the level of the whole, but not of the parts). The thesis of synchronic determination - a corollary of physical monism - states that a system's properties and behavioral dispositions depend on its microstructure: there can be no difference in systemic properties without there being some difference in the properties of the system's parts and/or in their arrangement. In turn, diachronic determination states that the coming into existence of new structures would be a deterministic process governed by natural laws (Stephan 1999: 31). This latter feature of emergentism is incompatible with Peirce's theoretical framework, as he rejected the belief in a deterministic universe (CP 6.201). However, this does not preclude the treatment of emergence in connection to a Peircean account of semiosis, as there are also emergence theories committed to indeterminism (e.g., Popper in Popper \& Eccles 1986 [1977]).

Semiosis is an emergent self-organizing process in a complex system of sign users interacting locally and mutually affecting each other (Loula et al., 2010). Queiroz and ElHani $(2012,2006 a, b)$ have modelled semiosis as an emergent, multi-level, process. Their model is based on Stanley Salthe's $(1985 ; 1993)$ hierarchical structuralist model of emergence, combining it explicitly with Peirce's triadic system of categories. Interested in Peirce's philosophy (Salthe, 1993: xi), Salthe has developed a multi-level hierarchical approach consisting of a "basic triadic system." We are going to describe below Peirce's triadic system of categories, and the model of semiotic emergence based on Salthe's basic triadic system.

The Peircean list of categories (Firstness, Secondness, Thirdness) can be described as a system of classes of irreducible logical, phenomenological and metaphysical components (see Houser 1997; Brunning 1997). In brief, the categories can be defined as follows: (1) Firstness: what is such as it is, without reference to anything else; (2) Secondness: what is such as it is, in relation with something else, but without relation with any third entity; (3) Thirdness: what is such as it is, insofar as it is capable of bringing a second entity into relation with a first one in the same way that it brings itself into relation with the first and the second entities. This system is the foundation of Peirce's philosophy and, also, of his model of semiosis (see Murphey 1993: 303-6). Firstness as a mode of being is a mere possibility. It can be characterized as lacking determination (cf. MS 277), and it is the category of vagueness and novelty. Secondness as a mode of being is an actual occurrence (Parker 1998; CP 6.455). It is the category of dyadic relations (CP 8.330) and reactions (CP 6.200). The actuality of a thing is simply its occurrence or the realization of a possibility, without thereby making reference to something larger, be that a general law or an interpretation. Thirdness is the category of mediation, habit, generality, and conceptualization (CP 1.340).

Queiroz and El-Hani's (2012, 2006,a,b) model of semiosis as an emergent multi-level phenomenon assumes that a description of semiosis need to consider at least three distinct levels of description: a focal level, a micro-semiotic level, and a macro-semiotic level. These levels are based on Salthe's hierarchical structuralist system. The focal level, in Salthe's model, is the level of observation of an actual phenomenon. This level is comparable to the Peircean logical phenomenological category of secondness, the consideration of actuality of occurrence. At this level we observe instantiated signs effectively acting and producing new instantiated signs. This dynamic action of signs has been modelled by Peirce as a chain of semiotic triads (see figure 1 above). This effective sign action is emergent, which in our approach means that it cannot be 
logically inferred from the behavior of parts of a system considered in simpler relations.

The micro-semiotic level is a lower level of description, that considers the components of the focal phenomenon. These components could be related in many possible ways, and the actual semiosis observed at the focal level is but one among many ways the phenomenon could have been instantiated. This level is comparable to the Peircean logical phenomenological category of firstness the consideration of elements of situated experience regardless of any actual connection or determination. At this level of description we can only regard the elements in their positive characters and situated possibilities of action, how they could act, but not how they will or would act. Here we observe not an actual semiotic chain, but only possible signs determining possible interpretants in relation to possible objects. In the domain of Firstness, we find a set of potential causal relations at the lower level, which can constitute a particular set of processes at the focal level. The examination of a micro-semiotic level of description establishes initiating conditions, or potentialities of action, but how a sign will act is indeterminable by this level alone. Hence, besides considering the micro-semiotic level of description we need also to consider a macro-semiotic level.

The emergence of effective sign action at the focal level is the result of an irreducible interplay of initiating and boundary conditions. An upward (micro to focal) constitutive determination on what will emerge can be described in the form of a potentiality of sign action provided by the components of a semiotic triad: potential signs, potential objects, potential interpretants. A downward (macro to focal) selective determination on what will emerge can be described in the form of a tendency of sign action given by a temporal or historical context. The irreducible interplay of these upward and downward determinative relations result in the emergence of effective sign action observed in the focal level (see figures 3 and 4).

The macro-semiotic level is a higher level of description, that considers an environment or context in which the focal phenomenon is framed or niched. This level is comparable to the Peircean logical phenomenological category of thirdness, the consideration of elements of situated experience as they are mediated by habits (general tendencies, regularities or law-like behaviors). In our description, this contextual level is a temporal context, and the habit is temporally distributed in the form of a cumulative and generalizable history of past sign action that tends towards some futures rather than others. This tendency plays the selective role of boundary conditions, that limit or constrain potentialities of action in terms of historical tendencies. At this level we describe a history of interconnected semiotic chains forming a past semiotic web or network that embeds habits of sign action. But the examination of a macro level of description doesn't allow us to infer how these habits will be instantiated. In order to do that, we have to consider the interaction between micro-semiotic and macro-semiotic level.

The emergence of effective sign action at the focal level is the result of an irreducible interplay of initiating and boundary conditions. An upward (micro to focal) constitutive determination on what will emerge can be described in the form of a potentiality of sign action provided by the components of a semiotic triad: potential signs, potential objects, potential interpretants. A downward (macro to focal) selective determination on what will emerge can be described in the form of a tendency of sign action given by a temporal or historical context. The irreducible interplay of these upward and 
downward determinative relations result in the emergence of effective sign action observed in the focal level (see figures 3 and 4). The process which will emerge at the focal level is among a set of processes made possible by the micro-structure of a given kind of system.

\begin{tabular}{|ccc|}
\hline macro-level & $\begin{array}{c}\text { boundary } \\
\text { conditions }\end{array}$ & $\begin{array}{r}\text { thirdness } \\
\text { (habit) }\end{array}$ \\
\hline focal-level & $\begin{array}{c}\text { observed } \\
\text { processes }\end{array}$ & $\begin{array}{r}\text { secondness } \\
\text { (event) }\end{array}$ \\
\hline micro-level & \multicolumn{2}{c|}{ potentiality } \\
\hline
\end{tabular}

Figure 3: A scheme of the determinative relationships in Salthe's hierarchical system in relation to Peirce's categories. Initiating conditions (associated with Peirce's category of firstness) and boundary conditions (associated with Peirce's category of thirdness) act together and irreducibly, determining an upward potentiality of action and a downward selective determination on the emergence of observed processes in the focal level (associated with Peirce's category of secondness).
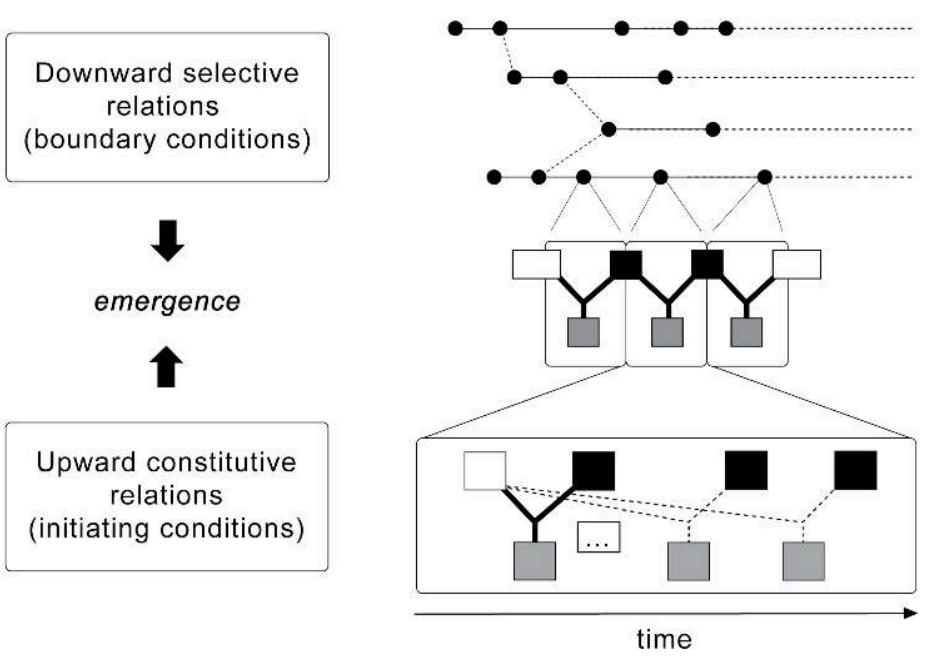

Macro-semiotic level

Focal level

Micro-semiotic level 
Figure 4: Micro-semiotic, macro-semiotic, and focal level of observations. At the focal level we observe effective dynamic sign action, that can be modelled as semiotic chains. At the microsemiotic level we observe possible sign action (represented by the dotted lines between possible semiotic triads). At the macro-semiotic level we observe networks of semiotic chains regulated by habits. The interaction between the micro-semiotic and the macro-semiotic level lead to the emergence of actual semiosis at the focal level.

An important assumption of this model is the ubiquity of semiotic emergence. In semiotic systems, every sign action is emergent. This is compatible with Peirce's distinction between dyadic brute force interactions on the one hand and triadic (mediated), semiotic, interactions on the other. Dyadic interactions can be analyzed in terms of dyadic relations: facts or logical relations of two terms. An example is the dyadic notion of reference. We may try to explain the vertical morphology of dance movements of the romantic ballerina as a reference to an ethereal being (say, a sylphide) because both the ethereal being and the dance movements share some qualities (lightness, verticality). This would be akin to seeing the ballerina and the sylphide as aggregate terms, correlated by a predicate (see CP 3.535). Dyadic relations allow us to describe systems that are reducible to aggregations of pairs of terms. However, such a description of reference in terms of a shared predicate says nothing about the higher level of the system itself, but only describes properties of aggregate terms. This kind of description is insufficient to account for semiotic relations. As previously described, semiotic relations are irreducibly triadic. To consider semiotic relations we have to increase the "order of relativity" (CP 3.625): from the mere dyadic correlation between terms, to a triadic relation in which a relation between two terms form a third correlate term, which is a whole (CP 7.537). A semiotic relation is not a fact about two terms, but instead a triple fact: what makes the relation between the romantic ballerina and the sylphide a semiotic relation is not the mere logical possibility that the ballerina and the sylphide share some qualities, but the power that this logical possibility acquires, within the context of a semiotic chain, of producing interpretants. In order to describe this triadic relation, we have to take into consideration not only the qualities of the elements, but a process that happens in the level of interpretative system itself. In other words, if a romantic ballerina is regarded as standing for a sylphide, we cannot explain this relation by considering only a predicate of the ballerina and of the sylphide; we have to consider the ballerina, the sylphide and the mediative action of ballet itself as a triple fact that is irreducible to a dyadic relation. It is in this sense that we can say that every sign action is emergent, and that this ubiquity of emergence is compatible to Peirce's description of semiosis as irreducibly triadic (and not dyadic). A consequence of this view is that semiotic chains and networks are constantly subjected to potential emergence of novelty: an aggregate pair of terms doesn't necessarily produce some interpretant. The stability of semiosis in time is not conceived as absence of novelty, but as regularity obtained across novelty.

Another important assumption of the model is the self-organization of semiotic chains and networks. Semiotic networks at the macro-semiotic level are constituted by past semiotic chains at the focal level, and in turn, help to further determine it. A consequence of self-organization of semiosis is that sign action is always to some degree self-referential: ballet signs instantiate ballet objects, ballet properties, ballet experiments, etc., that are considered pragmatically relevant in a certain context of practice that has itself been constructed by these objects, properties, experiments. This view is in opposition to the understanding of signs as conveyors of referential content. It is simplistic to attempt to characterize the semiotic process of ballet as dependent on 
some referential object independent of the semiotic process itself, because the whole complex is irreducibly dependent and self-constructed. The pragmatically relevant communication of self-referential properties of ballet renews or reiterates the capacity of this sign or system of signs (ballet) of semiotically structuring some contextual reality, or of conferring some useful agency to utterers and interpreters in relation to a given contextual reality. In this sense, whenever we talk about dancers, audience, or any cognitive artifacts involved in the action of the ballet sign, we consider them as signs whose action is emergent and integrate a self-constructed semiotic process.

\section{Emergence of Classical Ballet as a Sign in Action}

Classical ballet is an emergent sign in action. This sign in action is distributed in time (across the whole history of ballet), and defined as an open-ended tendency of development and pragmatic likelihood of occurrences of meaning processes. The emergence of classical ballet is the emergence of a habitual, self-organized, temporally distributed semiotic process. It involves several historical episodes, such as the leap from etiquette to art form with the codification of body positions during the reign of Louis XIV, the transfer of dance performances from court venues to theaters with proscenium arch stages, the professionalization of dance and the formation of professional dancers, the formation and development of a popular audience for ballet, several episodes of embodied research and stabilization of dance techniques (e.g., the emergence of the pointe technique, popularized by Marie Taglioni in the 1830's), several episodes of systematization and codification of dance vocabularies (e.g., such as the alphabet of dance steps published in Carlo Blasis' 1828 The Code of Terpsichore). At any of these episodes, the development of the semiotic chain is subjected to upward initiating conditions from a micro-semiotic level and downward boundary conditions from a macro-semiotic level.

A particular example that can illustrate the role of micro-semiotic and macro-semiotic levels concerns the proscenium arch stage. At a micro-semiotic level, the development of the semiotic chain of classical ballet is regulated by the availability of artifacts and the initiating conditions for sign action they embody. Consider the performance space of ballet. In its baroque origins in European courts, ballets were performed in palace halls or gardens, there were no elevated stages or proscenium arches, and the audience occupied seats arranged in tiers and viewed the spectacle from above (Cohen \& Matheson 1992; Homans 2010). This positioning of dancers in relation to the audience afforded geometric patterns of dancers' displacement in the performance space (see figure 5):

[T] he ballets were performed, not on raised stages, but in the central space of large halls with the audience seated above the floor in galleries that extended around three sides of the dancing area. The wise masters reasoned out that the way to dazzle was not with steps, which the performers could not do expertly and the audience could not see well, but with floor patterns - complex geometrical shapes that formed, dissolved, and reformed to display a tantalizing variety of designs. (Cohen \& Matheson 1992: 7) 


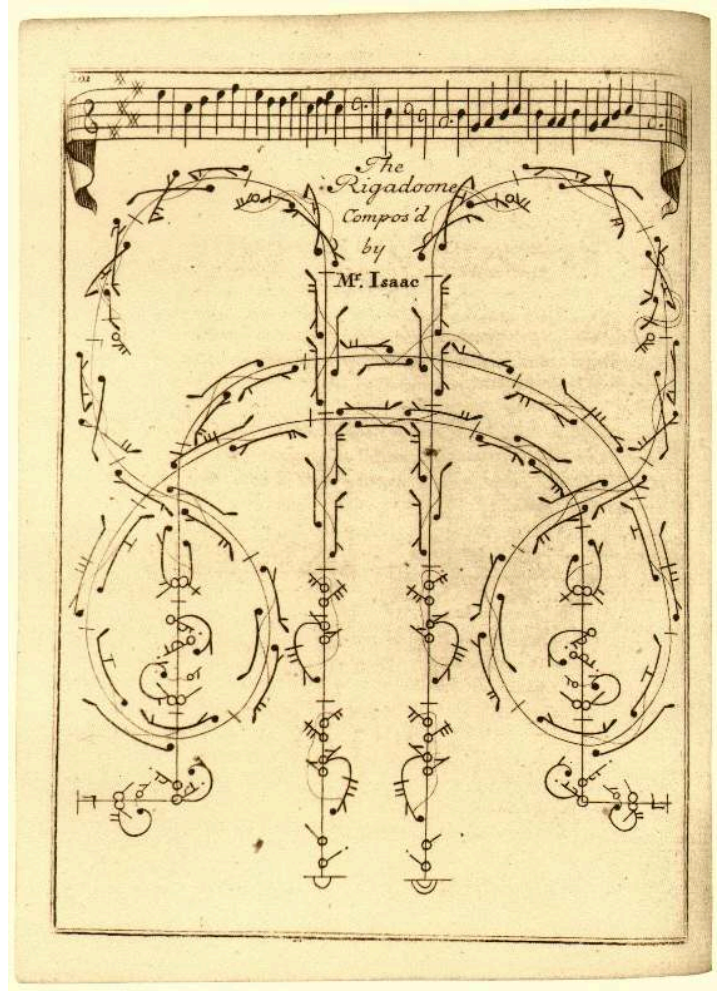

Figure 5: A 1721 dance as represented in the Beauchamp-Feuillet notation. The notation system itself stressed the geometrical character of the dancers' displacement as viewed from above. [upload.wikimedia.org/wikipedia/commons/1/1e/Feuillet_notation.jpg].

The historical development of classical ballet saw a transition from these performance spaces to proscenium arch stages as we typically know them. That corresponded to a change in the relation between dancers and audiences. The architecture of the proscenium arch stage offers a different set of initiating conditions for sign action incorporated in the performance space, as it locates the performance in front of the audience and frames it with the proscenium arch. The development of this kind of stage was directly influenced by visual perspective (see Breton 1990; Barker \& Bay 2016), a technique developed by Filippo Brunelleschi and Leon Battista Alberti in the context of architectural drawing and painting. The stage functions as a one-point perspective box that privileges frontality of observation.

Regardless of wider historical or contextual considerations, the frontality of observation afforded by the cognitive artifact of the proscenium arch stage already imposes new initiating conditions for sign action. However, when we consider actual semiosis, this set of initiating conditions are always acting together with a macrosemiotic level, subjected to a regulatory process that involves a network of semiotic chains. When we consider the proscenium arch stage in ballet, a relevant semiotic chain concerns the construction of the body of the dancer as a sign endowed with meaning. This extensive semiotic chain includes, among others, the contrapposto of Classical Antiquity statuary, the Renaissance aesthetic ideal of mathematically harmonious body proportions, the Pythagorean academic association between body, music and mathematics in 16th century France (Homans 2010: 5), the severe discipline of body movements established by the etiquette of the French court, the posture and footwork of fencing. This historical regulation had before determined the 
geometrically-precise body of the baroque dancer as the dancing body performing in the halls and gardens for an audience of nobles and courtiers. The introduction of the proscenium arch stage and its new set of initiating conditions was followed by new retranslations of the ballet dancer as a sign. In the eighteenth century, the ballet master creator of the ballet d'action, Jean George Noverre, likened the perspective box of the proscenium arch stage to the tableaux of a painting, and put forward a conception of ballet as a dynamic painting. Noverre emphasized pictorial composition and narrative, chiaroscuro, and perspective, suggesting that dancers be assigned roles according to their stature so as to emphasize the perspectival illusion of depth, and introducing pauses in the ballet action so that the audience could take time to appreciate the details of the visual compositions of his balletic tableaux (Monteiro 1998, ch. 2; Homans 2010: 74). The intersemiotic relation (relation between different semiotic systems) with painting regulated how the frontality of observation afforded by the proscenium arch stage theater acted semiotically in the ballet d'action. The frontality of observation afforded by the proscenium arch stage also provides initiating conditions for the romantic revolution that marks the start of modern ballets (see Homans 2010: 170). Romantic ballet was decisively dependent on vertical morphologies of dance movement. The influential dancer Marie Taglioni, the first romantic ballerina, stabilized into a balletic habit the en pointe technique (dancing on the tip of the toes), helping to form the ideal image of the ballerina as an ethereal and weightless figure. This verticality of dance went together with Romanticist aesthetic ideals. In fact, as indicated by Homans, Taglioni's career represents a central point of connection between ballet and French literary Romanticism:

Robert le Diable [1831 opera including a ballet performed by Taglioni] opened ballet to the world of literary Romanticism. In the years to come, a generation of poets, writers, and artists found themselves drawn to Taglioni and to dance. Heine, Stendhal, Balzac, Théophile Gautier, and Jules Janin all wrote about ballet. The poems and stories of Sir Walter Scott and E.T. A. Hoffmann, Victor Hugo and Charles Nodier, served as inspiration for ballet masters, and both Heine and Gautier wrote ballet librettos of their own. Perhaps most important of all, and building on Noverre, these poets and writers understood that ballet was not merely an aspect of opera but had a distinct language of its own: they were its first informed critics. Nor was their role merely responsive or passive, for their writings defined Taglioni's image and played a critical role in promoting her career. (Ibid.: 150-1)

Both Noverre's pictoric ballet and the verticality of dance of the romantic ballerina are retranslations of the body of the ballet dancer as a sign. They presuppose the frontality of observation afforded by the proscenium arch stage, and submit it to the regulatory influence of past sign action (perspective in painting in the case of Noverre, literary Romanticism in the case of Taglioni). These operations create novel processes of meaning, emergent episodes of sign action.

\section{Conclusion}

In classical examples of distributed cognition, sign action is distributed within spatial contexts: boats (Hutchins 1995a), cockpit of an airplane (Hutchins 1995b), research laboratory (Nersessian et al. 2003), theater building (Tribble 2005). In these examples, the distribution of cognition is decisively conceived as a matter of spatial locus: cognition is not only located in the head of individuals, but in spatial environments of cognitive artifacts and cultural practices. In our approach, the focus of description of 
distributed sign action is not spatial, but temporal. It is not only the case that a sign cannot simply be described as spatially contained within one's skull, it is also (and more centrally) the case that a sign cannot be described as temporally contained within one event or episode. Even when the focus of observation is effective instantiated sign action in a single event, the sign acts as a temporally distributed process in which a regular tendency towards certain future outcomes emerges out of a history of sign interactions.

Our most fundamental explanatory unit is sign action, a temporally distributed process. This is what grounds our emergentist account of cognition. Semiosis self-organizes in time, in a process that continuously entails the production of more signs. Emergence is a ubiquitous condition in this process: the translation of signs into signs cannot be inferred from the properties of the components of a semiotic triad alone, but has to take into account a complex interaction between a micro-semiotic and macro-semiotic level of description. This interaction can be understood as an interplay of potentialities and tendencies, or upward constitutive determinative relations and downward selective determinative relations. According to this view, emergence is a central defining condition of processes of meaning. The emergence of sign action is associated with novelty, creativity, and surprise in cultural evolution.

Ballet is a sign in action. It is a unique process of meaning that continues to emerge in time through the interplay of material situated conditions afforded by cognitive artifacts at a given moment and habits of sign action within networks of semiotic chains. This process has emerged as a relation of meaning involving different kinds of cognitive artifacts: musical, bodily/motor, visual and pictoric, spatial and architectonic, etc. Before the emergence, these cognitive artifacts developed according to various semiotic habits: e.g., etiquette and fencing regulated body discipline, perspective regulated the architectonic space of theatre stages and the pictoric space of the canvas. In classical ballet, a novel and unique habit emerges that regulates the behavior of several cognitive artifacts. One case is the development of the verticality of dance in classical ballet as a semiotic relation connecting proscenium arch stages and dancers as temporally distributed signs. This development is micro-semiotically determined by the spatial conditions of the proscenium arch stage, and macro-semiotically determined by a historical construction of the body of the dancer within a network of semiotic chains, such as the body of the dancer as a pictoric object in a painting tableaux organized by one-point perspective, or as an embodiment of the aesthetic ideals of literary Romanticism. This is not only the emergence of actual meaning, but also the emergence of an open-ended field of potential and general meanings, a selforganized and temporally-distributed semiotic process.

\section{BIBLIOGRAPHY}

ATÃ Pedro \& João QUEIROZ, (2016), "Habit in Semiosis: Two Different Perspectives Based on Hierarchical Multi-level System Modelling and Niche Construction Theory," in D. West \& 
M. Anderson (eds), Consensus on Peirce's Concept of Habit: Before and Beyond Consciousness, Springer, 109-19.

ATÃ Pedro \& João QUEIROZ, (in press), “A Peircean Semiotic Approach to Distributed Cognitive Systems: A Description of Brazilian Sung Poetry Improvisation," Zeitschrift für Semiotik.

ATKIN Albert, (2016), Peirce, London, Routledge.

BARKER Clive \& Howard BAY, (2016), Baroque Theatres and Staging. Online: [britannica.com/art/ theater-building/Baroque-theatres-and-staging].

BRETON Gaëlle, (1990) Theater, Stuttgart and Zürich, Karl Krämer.

BRUNNING Jacqueline, (1997), “Genuine Triads and Teridentity," in N. Houser, D. Roberts \& J. Van Evra (eds), Studies in the Logic of Charles Sanders Peirce, Indiana, Indiana University Press, 252-70.

BURCH Robert W., (1997), "Peirce's Reduction Thesis," in N. Houser, D. Roberts \& J. Van Evra (eds), Studies in the Logic of Charles S. Peirce, Indiana, Indiana University Press, 234-51.

COHEN Selma Jeanne \& Katy MATHESON, (1992), Dance as a Theatre Art: Source Readings in Dance History from 1581 to the Present (2nd ed.), Princeton, NJ, Princetoon Book Company.

DAVIES Jim \& Kourken MICHAELIAN, (2016), “Identifying and Individuating Cognitive Systems: A Task-Based Distributed Cognition Alternative to Agent-Based Extended Cognition," Cognitive Processing 17, 307-19.

DE TIENNE André, (2003), “Learning qua semiosis," Semiotics, Evolution, Energy, and Development Journal 3, 37-53.

DE WAAL Cornelis, (2013), Peirce - A Guide for Perplexed, London, Bloomsbury.

ENGEL Andreas K., FRISTON Karl J. \& Danica KRAGIC (eds), (2016), The Pragmatic Turn: Toward ActionOriented Views in Cognitive Science, Cambridge, MA, MIT Press.

ESPOSITO Joseph, (2005), “Synechism: the Keystone of Peirce's Metaphysics," in M. Bergman \& J. Queiroz (eds), The Commens Encyclopedia: The Digital Encyclopedia of Peirce Studies. New Edition. Online: [commens.org/encyclopedia/article/esposito-joseph-synechism-keystonepeirce\%E2\%80\%99s-metaphysics].

FISCH Max H., (1986), Peirce, Semeiotic and Pragmatism: Essays by Max H. Fisch, Kenneth Laine Ketner \& Christian Kloesel (eds), Indianapolis, Indiana University Press.

FLOWER Elizabeth \& Murrey MURPHEY, (1977), A History of Philosophy in America, vol. II, Capricorn Books.

HAUSMAN Carl R., (1993), Charles Sanders Peirce's Evolutionary Philosophy, Cambridge, Cambridge University Press.

HOMANS Jennifer, (2010), Apollo's Angels: A History of Ballet-Random House, New York, Random House. ноокWAY Christopher, (1985), Peirce, London, Routledge \& Kegan Paul.

ноокwAY Christopher, (2002), Truth, Rationality, and Pragmatism: Themes from Peirce, Oxford, Clarendon Press.

HOUSER Nathan, (1997), "Introduction: Peirce as a Logician," in N. Houser, D. Roberts \& J. Van Evra (eds), Studies in the Logic of Charles Sanders Peirce, Indiana, Indiana University Press, 1-22.

HUTCHINs Edwin, (1995a), Cognition in the Wild, Cambridge, MA, MIT Press.

HUTCHINS Edwin, (1995b), “How a Cockpit Remembers its Speeds," Cognitive Science 19, 265-88. 
HUTCHINs Edwin, (1999), “Cognitive Artifacts," in R. A. Wilson \& F. C. Keil (eds), The MIT Encyclopedia of the Cognitive Sciences, Cambridge, MA, MIT Press, 126-8.

HUTCHINS Edwin, (2014), “The Cultural Ecosystem of Human Cognition," Philosophical Psychology, 27 (1), 34-49.

KELSO Scott J. A., (1995), Dynamic Patterns: The Self-Organization of Brain and Behavior, Cambridge, MA, MIT Press.

LEGG Catherine \& Christopher hookway, (2019), "Pragmatism," in E. N. Zalta (ed.), The Stanford Encyclopedia of Philosophy (Spring 2019 Edition). Online: [plato.stanford.edu/archives/spr2019/ entries/pragmatism/].

LOULA Angelo \& João QUEIROZ, (2011), "Modeling the Emergence and Evolutionary History of Semiotic Systems and Processes," International Journal of Signs and Semiotic Systems 1, i-iv. LOULA Angelo, GUDWIN Ricardo, EL-HANI Charbel Niño \& João QUIEROZ, (2010), “The Emergence of Self-Organized Symbol Based Communication in Artificial Creatures, " Cognitive Systems Research 11, 131-47.

MADZIA Roman \& Matthias JUNG (eds), (2016), Pragmatism and Embodied Cognitive Science from Bodily Intersubjectivity to Symbolic Articulation, Bremen, Walter de Gruyter.

MENDES Miriam Garcia, (1987), A dança, São Paulo, Editora Ática.

MONTEIRo Marianna, (1998), Noverre: Cartas sobre a dança, São Paulo, Edusp.

MONTEIRo Marianna, (1999), "Balé, tradição e ruptura," in R. Pereira \& S. Soter (eds), Lições de dança, Rio de Janeiro, UniverCidade Editora, 169-89.

MURPHEY Murray G., (1993), The Development of Peirce's Philosophy, Indianapolis, Hackett.

NERSESSIAN Nancy J., KURZ-MILCKE Elke, NEWSTETTER Wendy C. \& Jim DAVIES, (2003), “Research Laboratories as Evolving Distributed Cognitive Systems," in R. Alterman \& D. Kirsh (eds), Proceedings of the Twenty-Fifth Conference of the Cognitive Science Society, Boston, Cognitive Science Society, 857-62.

PARKER Kelly A., (1998), The Continuity of Peirce's Thought, Nashville,Vanderbilt University Press. PEIRCE Charles Sanders, (EP1, 1992; EP2, 1998), The Essential Peirce: Selected Philosophical Writings, vol. 1 N. Houser \& C. Kloesel (eds); vol. 2 ed. by the Peirce Edition Project, (Bloomington and Indianapolis, Indiana University Press.) (Quoted as EP, followed by volume and paragraph.) PEIRCE Charles Sanders, (1931-1935), The Collected Papers of C. S. Peirce, vols. I-VI. eds. C. Hartshorne \& P. Weiss, Cambridge, Harvard University Press, 1931-1935]; vols. VII-VIII [A. W. Burks (ed.), same publisher, 1958], Charlottesville, Intelex Corporation. (Quoted as CP, followed by volume and paragraph.)

PEIRCE Charles Sanders, (1967), Annotated Catalogue the Papers of C. S. Peirce. R. S. Robin (ed.), Massachusetts, The University of Massachusetts Press. (Quoted as MS, followed by the number of the manuscript.)

POPPER Karl R. \& John C. ECCLES, (1986 [1977]), The Self and its Brain, London, Routledge and Kegan Paul.

POTTER Vincent G., (1997), Charles S. Peirce: On Norms and Ideals, Amherst, University of Massachusetts Press. 
QUEIROZ João \& Charbel Niño EL-HANI, (2006a), “Semiosis as an Emergent Process," Transactions of the Charles S. Peirce Society: A Quarterly Journal in American Philosophy, 42 (1), 78-116.

QUEIROZ João \& Charbel Niño EL-HANI, (2006b), “Towards a Multi-Level Approach to the Emergence of Meaning in Living Systems," Acta Biotheoretica 54, 179-206.

QUEIROZ João \& Charbel Niño EL-HANI, (2012), “Downward Determination in Semiotic Multi-level Systems," Cybernetics \& Human Knowing - A Journal of Second Order Cybernetics, Autopoiesis \& Semiotics 19, 123-36.

SALTHE Stanley N., (1985), Evolving Hierarchical Systems: Their Structure and Representation, New York, Columbia University Press.

SALTHE Stanley N., (1993), Development and Evolution: Complexity and Change in Biology, Cambridge, MA, MIT Press.

SAVAN David, (1988), “An Introduction to C. S. Peirce's Full System of Semeiotic,” Toronto Semiotic (Circle, Monograph Series of the TSC, Number 1).

STEPHAN Achim (1999), Emergenz: Von der Unvorhersagbarkeit zur Selbstorganisation, Dresden and Mü nchen, Dresden University Press.

TRIBBLE Evelyn B., (2005), “Distributing Cognition in the Globe," Shakespeare Quarterly, 56 (2), $135-55$.

WEST Donna E. \& Myrdene ANDERSON (eds), (2016), Consensus on Peirce's Concept of Habit: Before and Beyond Consciousness, (volume 31 of the series Studies in Applied Philosophy, Epistemology and Rational Ethics), Berlin, Springer.

ZHANG Jiajie \& Vimla L. PATEL, (2006), "Distributed Cognition, Representation, and Affordance," Pragmatics \& Cognition, 14 (2), 333-41.

\section{NOTES}

1. We follow the practice of citing from the Collected Papers of Charles Sanders Peirce (Peirce 1931-35, 1958) by volume number and paragraph number, preceded by CP; the Essential Peirce, by volume number and page number, preceded by EP. References to the Annotated Catalogue of the Papers of Charles S. Peirce (1967) will be indicated by MS, followed by the manuscript number and pages.

2. Peirce's semiotics is oriented by a philosophical principle of continuity, which Peirce refers to by the neologism "synechism." Synechism is a "tendency to regard everything as continuous" (CP 7.565). According to Peirce (CP 6.169), synechism is "[...] that tendency of philosophical thought which insists upon the idea of continuity as of prime importance in philosophy and, in particular, upon the necessity of hypotheses involving true continuity [...]." Synechism is first and foremost a methodological principle, "a maxim to look for connections and continuous strata between seemingly disconnected entities or events" (Esposito 2005, Introduction, par. 1). This principle of continuity abhors substantial dualism - the notion that psychical and physical phenomena are two completely separated categories of being - which Peirce refers to as "the philosophy which performs its analyses with an axe, leaving, as the ultimate elements, unrelated chunks of being" (Peirce 1893/1998, EP 2:2). Although Peirce construes his principle of continuity as a methodological principle, it points to a metaphysical hypothesis: "On the metaphysical side synechism is a hypothetical description of a tightly woven universe, a universe woven not within 
layers of the same kind of reality but between layers in a scalar fashion." (Esposito 2005, Introduction, par. 1).

\section{ABSTRACTS}

We explore Peirce's pragmatic conception of sign action, as a distributed and emergent view of cognition and exemplify with the emergence of classical ballet. In our approach, semiosis is a temporally distributed process in which a regular tendency towards certain future outcomes emerges out of a history of sign actions. Semiosis self-organizes in time, in a process that continuously entails the production of more signs. Emergence is a ubiquitous condition in this process: the translation of signs into signs cannot be inferred from the properties of the components of a semiotic triad alone, but has to take into account a complex interaction between a micro-semiotic and macro-semiotic level of description. This interaction can be understood as an interplay of potentialities and tendencies, or upward constitutive determinative relations and downward selective determinative relations. According to this view, emergence is a central defining condition of processes of meaning.

Ballet is a sign in action. The emergence of classical ballet is a self-regulatory process, in which a system of different kinds of cognitive artifacts (musical, bodily/motor, spatial/architectonic) and agents obtained a stable semiotic relation throughout many phases of development between the 16th and the 19th Century. One case is the development of the verticality of dance in classical ballet as a semiotic relation connecting proscenium arch stages, dancing bodies, and audiences. This development is micro-semiotically determined by the spatial constraints of the proscenium arch stage, and macro-semiotically determined by a historical construction of the dancing body as a sign within a network of semiotic chains, such as the intersemiotic regulation of body of the dancer by principles coming from painting. This is not only the emergence of actual meaning, but also the emergence of an open-ended field of potential and general meanings, an autonomous tendency of development. To say that ballet, as sign action, emerges, is to say that cognitive artifacts such as dancer's bodies, stages and audience's point of view, musical compositions, costumes, all sorts of supporting institutions, etc, constitute a niche for sign action, interacting according to tendencies of development that didn't exist before.

\section{AUTHORS}

\section{PEDRO ATÃ}

Centre for Intermedial and Multimodal Studies, Linnaeus University, Sweden pedro.ata[at]lnu.se

\section{JOÃO QUEIROZ}

Institute of Arts, Federal University of Juiz de Fora, Brazil

queirozj[at]gmail.com 